\title{
The Effect of Summary Writing as a Critical Reading Strategy on Reading Comprehension of Iranian EFL
}

\section{Learners}

\author{
Nasrin Shokrpour (Corresponding author) \\ English Department, Paramedical Sciences Faculty \\ Shiraz University of Medical Sciences, Iran \\ Tel: 98-711-228-9113Ｅ-mail: shokrpourn@gmail.com
}

Azin Sadeghi

Freelance, Iran

Fatemeh Seddigh

English Department, Paramedical Sciences Faculty

Shiraz University of Medical Sciences, Iran

Received: Nov. 8, 2012

Accepted: February 24, 2013 Published: May 1, 2013

doi:10.5296/jse.v3i2.2644

URL: http://dx.doi.org/10.5296/jse.v3i2.2644

\begin{abstract}
Critical pedagogical approach entails the application of higher order thinking skills; such an approach can also be justified in more specific terms for second or foreign language pedagogy. That is, critical reading, as a branch of critical approach, is not only of value in itself, but also facilitates language acquisition in a foreign language setting (Wallace, 2003). On the other hand, reading has been the skill most emphasized in traditional FL teaching, and even today it is the mainstay of EFL instruction in many countries. Nowadays, in the field of ESL/EFL, the ultimate goal of teaching reading is reading critically, to be able to evaluate an author's argument and to relate that argument to other texts, and to their own experience. Reading critically assumes having effective strategies which help reading comprehension. The present study investigated the impact of writing summary as a critical reading strategy on reading comprehension ability of Iranian EFL learners. In order to carry on the study, 60 participants at intermediate level of language proficiency were randomly assigned to two
\end{abstract}


groups as the experimental and control group. The participants in the experimental group learned and practiced writing summary, whereas the members of the control group practiced reading texts in the traditional way and both groups answered comprehension questions. The results of the comparison between the means of the two groups through t-test proved that writing summary as a critical reading strategy has a significant effect on improvement of reading comprehension of the experimental group.

Keywords: Critical Reading, Reading Comprehension, Critical Reading Strategies, Summary Writing Strategies 


\section{Introduction}

Reading has been the skill most emphasized in traditional English as a Foreign Language (EFL) teaching and even today is the mainstay of EFL instruction in many countries. Recently, there has been interest in reading as a social, critical process (Wallace, 1992; Baynham, 1995). The claim is that readers do not need to accept the words on the page as given, but a range of interpretations are legitimate. They should be able to synthesize new ideas with their background knowledge, identify the relationships between different pieces of information or express their agreement or disagreement about the opinion of the writer. Learners need to use specific strategies to reach these objectives. The procedures which are employed to discern the content of text and subsequently analyze and evaluate it are commonly known as critical reading strategies. It is confirmed that critical reading is not only for value in itself, but also it facilitates foreign/second language acquisition setting (Wallace, 2003). Critical reading includes many strategies such as evaluating, analyzing, reading with purpose, ... one of the most important of which is summary writing. Naturalistic studies of second language literacy acquisition show that reading and writing cannot be separated from each other and summary writing can be influential in reading comprehension (Belcher \& Connor, 2001; Spack, 1997).

In Iran, as a matter of fact, critical reading strategies are not normally employed in language classes. Learners engage in reading through common reading practices, like answering multiple choice questions, true-false statements and supplying synonyms and antonyms for the new vocabulary of the lesson. Additionally, teachers have a propensity for getting prompt feedback from learners' reading comprehension ability. It seems that teachers do not challenge the dominant four skills view or an integrated approach in teaching reading skill to learners. Consequently, participants do not express their opinion about the texts and are reluctant to discuss the underlying meaning of the texts.

\subsection{Review of Related Literature}

Critical reading as a branch of critical approach has attracted the attention of many researchers in the recent years. Schallert and Reed (2004) subscribe to the view that reading skill as an evaluative tool can have a basic role in bringing the spirit of self-awareness and criticality language to classes. Therefore, EFL learners should learn how to engage in the process of critical reading. It means that learners should be persuaded to question the assumptions of the writers rather than accepting them as established facts (Goatly, 2000).

There are few studies on critical reading in EFL context. For example, Icmez (2009) explored the ways in which critical reading (CR) practices can be adapted to traditional EFL reading lessons to increase the students' motivation to learn English. Koupaee Dar and her colleagues (2010), at Kashan University, investigated the improvement of critical reading abilities of EFL students after teaching critical reading techniques. In addition they surveyed any change in students' views toward learning English language and in their critical language awareness. After the examination of students' analyses and the investigation of their answers given to the questionnaire, it was revealed that critical language awareness of about $90 \%$ of students increased. Their motivation also enhanced in learning English language after becoming 
familiar with the field of critical reading and they became interested to read critically.

According to Bosely (2008), many college instructors assume that high school graduates can "read critically", but much research suggests that for some students critical reading strategies must be taught explicitly and reinforced through practice. As Koupaee Dar et al. (2010) point out, Iranian students are mostly passive non-critical, rote-learning students who do not participate in deep learning. Maybe, one of its reasons is the student's lack of some important reading comprehension and critical reading strategies.

Missori (2007) introduces seven critical reading strategies which he claims help students read critically and confidently. These strategies are:

- Annotating

- Previewing

- Contextualizing

- Questioning

- $\quad$ Reflecting

- $\quad$ Summarizing

- Evaluating an argument

He believes that summarizing begins with outlining, but instead of merely listing the main ideas, a summary recomposes them to form a new text. In fact, a summary is a writing activity helping the learners to flourish their writing skills. It helps them to put the main points of the text together rather than outlining it by compacting an idea. Summarizing depends on a close analysis of each paragraph and creative synthesis. It shows how reading critically can lead to deeper understanding of any text. Moreover, reading and writing are closely related and support each other. Caccamise (2011) considered summarizing as an important reading comprehension skill that can help learners develop the gist of ideas and shape a lasting and exact "text based representation of text meaning.

The impact of strategy use on foreign and second language learning have been explored in many researches, for example, Nassrollahi (2007), examined the relationship between activating background strategy, as a critical reading strategy, and reading comprehension autonomy of EFL Iranian learners. The results demonstrated that critical reading strategy positively affected the students' reading comprehension. In addition, Arju (2010) reported that if the instructor asks EFL learners to write their personal opinions after reading a piece of passage, as one of the critical reading strategies, they will improve on reading comprehension ability. She applied this method in her reading comprehension class in Stamford University Bangladesh and achieved obtained a satisfactory result.

In a case study conducted by Correia (2006), with a group of advanced university students in Brazil, the researcher examined the effect of writing summary and discussing about the article on the students' reading comprehension. Correia got the result that writing summary 
has positive effect on reading comprehension of her students. Baleghizadeh and Babapur (2011) conducted a study about the effect of summary writing on reading comprehension and recall of Iranian EFL learners. Their subjects consisted of 50 intermediate female students who were divided into two groups. The first group was asked to read a text and write the summary of it and the second group read it without writing the summary. For evaluation, the two groups were given a reading comprehension test with 20 multiple choice questions. The results showed that summary writing promoted the reading comprehension of Iranian EFL learners. The findings also indicated that the importance of summary writing tasks should be considered in designing teaching material.

The reciprocal relationship between reading and writing was studied by Graham and Herbert (2010) to find out the impact of writing on reading activities. They noticed that having learners write about the texts they have read can improve their abilities in reading. Also, Pakzadian and Eslami Rasekh (2012) explored the effect of summarization strategies instruction on Iranian EFL learners' level of reading comprehension. Their subjects were 40 undergraduates (20 males and 20 females) at Payam Noor University. The results revealed a statistically significant difference between the learners' reading comprehension performance before and after the instruction. However, the difference between the performance of male and female participants was not statistically significant.

\subsection{Significance of the study}

To the best of our knowledge, in spite of the increasing popularity of the research on critical reading, its strategies are still a new research area in universities in the EFL context. The aim of the present study was to survey the effect of summary writing as one of the critical reading strategies on reading comprehension of EFL learners in an English language institute in Iran.

Based on the objective of the study, the following question is addressed:

Does the application of writing the summary of texts as a critical reading strategy have any significant effect on improving reading comprehension of EFL learners?

Based on the aforementioned research question, it is hypothesized that the application of summary writing strategy affects reading comprehension of EFL learners. Accordingly, the following null hypothesis is proposed:

The application of summary writing strategy has no significant effect on reading comprehension of EFL learners.

\section{Material and Method}

The present study can be categorized generally as a true experimental research and in particular casual- comparative.

\subsection{Participants}

70 female EFL learners studying at level 2 of TOEFL pre-requisite courses at Kish Language School in Fasa were the subjects of this study. These students had taken a placement test for entering these courses and they were at the same level of language proficiency, namely 
intermediate. As the homogeneity of reading comprehension proficiency of the participants was critical in this study, TOEFL (2007) reading comprehension proficiency test was administered. The results obtained agreed with that of the placement test. Therefore, the subjects were considered as intermediate level of reading comprehension ability. Although 70 learners originally participated at TOEFL reading comprehension proficiency test, 60 of them whose scores were one standard deviation above and below the mean were chosen as the key informants. The students' age ranged from 19 to 28 with an average of 24.5 years. All the participants had studied English for at least 8 years.

\subsection{Instruments}

1. A proficiency test in reading comprehension skill from TOEFL tests (2007) used as pre-test.

2- Other versions of TOEFL reading comprehension tests (2007) were used as post-tests of reading comprehension. All the tests included three passages and 36 multiple choice items. 3- The materials used for treatment were the articles of Summit (1B) book as the course book of Kish Language School.

4- Guidelines for Summary Writing, based on Bell and Gower (2000).

\subsection{Procedure}

In this study, 70 female intermediate EFL learners who were studying English in Kish Language School were chosen using cluster sampling. In this sampling method, the population is divided into separate groups called clusters; then a simple random sample of clusters is selected from the population. The analysis of data is done on the sampled clusters. In this sampling method, this In order to choose the subjects with the same level of reading comprehension ability which is the dependent variable in this study, a TOEFL reading comprehension test was administered as a proficiency test as the pre-test. Of the initial 70 learners, 60 scored within one standard deviation above and below the mean, and consequently they were included in the study as the key informants. The 30 selected subjects were randomly assigned as the experimental group and the other 30 as the control group. The students in both groups took a pre-test on reading comprehension at the beginning of the semester using TOEFL reading comprehension test (2007) which showed the present level of their reading comprehension ability. Afterwards, the two experimental and control groups undertook six weeks of instruction: two sessions a week, each session lasting 45minutes of reading comprehension. The same passages from Summit (1B) book were taught in both groups. The teacher worked on the vocabulary, reading strategies through different exercises and only the students in the experimental group were asked to write the summaries of the articles they had read. As summary writing is a difficult task, the instructor taught students how to write one and explained the qualities of a good summary. The subjects in the control group were not taught summary writing and were not asked to write the summaries of the passages.

After the treatment, the participants in both groups took part in reading comprehension post-test. In the experimental group, the learners were asked to write the summary of the 
passage they had read and then answer the questions.

\section{Data Analysis}

The data were analyzed in SPSS, version 16, using descriptive statistics and independent sample t-test

\section{Results}

To answer the research questions of this study, the mean and standard deviation of both groups were calculated. The descriptive statistics of the pre-test are presented in Table 1.

Table 1. The students' mean scores and standard deviation in the pre-test

\begin{tabular}{|l|l|l|l|}
\hline Groups & $\mathbf{N}$ & $\begin{array}{l}\text { Mean } \\
\text { Scores }\end{array}$ & $\begin{array}{l}\text { Standard } \\
\text { Deviation }\end{array}$ \\
\hline Experimental & 30 & 17.46 & 2.57 \\
\hline Control & 30 & 17.33 & 2.60 \\
\hline
\end{tabular}

As shown in Table 1, the experimental and control groups have got nearly equal means. This indicates that the subjects of both groups are homogenous. To compare the students' reading comprehension performance in the pre-test, a t-test was run. Since we had a sample size 30 in two groups (experimental and control), the total degree of freedom is 58. The number of d.f., 58 , is not listed in the t-value table but it is very near to 60 . Therefore, 60 was chosen as being the more conservative estimate and it was checked across to the 0.05 column. The result of t-test analysis is shown in Table 2.

Table 2. Comparison of both groups in the reading comprehension pre-test

\begin{tabular}{|l|l|l|}
\hline The computed T & Degree of Freedom & $\begin{array}{l}\text { Significance } \\
\text { Level }\end{array}$ \\
\hline 2 & 58 & 0.89 \\
\hline
\end{tabular}

Significant at $\mathrm{p}<0.05$

The results confirm the homogeneity of the proficiency level of the two groups. There was no significant difference between the students' reading performance in the pre-test. $(0.89<2)$

One session after the six weeks of intervention, the post-test was administered. The data gathered from the post-test were analyzed and the descriptive statistics of both experimental 
and control groups are presented in Tables 3 and 4.

Table 3. The mean and standard deviation of the experimental group in the post-test

\begin{tabular}{|l|l|l|l|}
\hline Group & Number & Mean Score & Standard Deviation \\
\hline Experimental & 30 & 18.43 & 3.01 \\
\hline
\end{tabular}

The value of mean and standard deviation of control group is shown in Table 4.

Table 4. Mean and standard deviation of the control group in the post-test

\begin{tabular}{|l|l|l|l|}
\hline Group & $\mathbf{N}$ & Mean Score & Standard Deviation \\
\hline Control & 30 & 17.76 & 3.29 \\
\hline
\end{tabular}

By comparing the mean values of the control group in the post-test and pre-test, it can be noticed that the scores of the control group have also increased from 17.33 to 17.76 . But this improvement is not as much as that of the experimental group in the post-test. The two groups scored differently in the post-test and the results of the t-test revealed that the difference between them was statistically significant. (Table 5)

Table 5. Mean and standard deviation of both groups in the post-test

\begin{tabular}{|l|l|l|l|}
\hline Groups & Number & Mean Scores & Standard Deviation \\
\hline Experimental & 30 & 18.43 & 3.01 \\
\hline Control & 30 & 17.76 & 3.29 \\
\hline
\end{tabular}

To compare the performance of both groups in the post-test, the second t-test was run. The results of the paired sample tests are shown in Table 6.

Table 6. Comparison of both groups in the reading comprehension post-test

\begin{tabular}{|l|l|l|}
\hline The computed T & Degree of Freedom & Significance Level \\
\hline 2 & 58 & 2.27 \\
\hline
\end{tabular}

As shown in Table 6, the null hypothesis is rejected (2.27>2). In other words, the treatment 
was effective enough to make a significant difference between the experimental and the control groups' reading comprehension.

Rejecting the null hypothesis at 0.05 level of significance indicates that a difference in means as large as that found between the experimental and control group would not have resulted from sampling error in more than 5 out of 100 replications of the experiment. This suggests a 95 percent probability that the difference was due to the experimental treatment rather than to the sampling error. Therefore, it can be concluded that the use of critical reading strategy would make a difference in teaching reading comprehension when applied to similar populations of EFL learners.

\section{Discussion}

Developing reading ability is not an easy task for most of the students especially in EFL contexts where exposure to language is limited to just few hours in a week. In this study the effect of summary writing as a critical reading strategy on reading comprehension has been examined. Since reading comprehension requires mental involvement and self-awareness of the language learners, the positive answer to the research question reveals that this strategy provides the needed opportunity for the learners.

During the treatment, the researcher observed that even when all of the main ideas were included in the summaries, there were a variety of possible interpretations, each based on the student's particular perspective of the text. By discussing about the summaries in class, the students realized that writing is never totally objective and the critical reader can always find something of the writer's bias or particular point of view in a text. The aim of summary writing treatment is that the students discover that multiple interpretations are acceptable and, indeed, they should be encouraged in a reading class that aims to develop critical reading skills and comprehension. Furthermore, by using this strategy in reading classes, teachers can budget their class time and simultaneously work on both reading and writing ability of their students. Teachers should consider that summary writing strategy not only strengthens the spirit of self- awareness and critical thinking among language learners, but also bridges the gap between reading and writing skill. This finding supports Shen's (2009) claim that reading- writing connection can improve EFL college learners' reading comprehension.

A lot of research has been done on the relationship between critical reading strategies and reading comprehension (Ghahraki \& Sharifian, 2005; Nasrollahi 2007; Arju 2010; etc.) and confirm the positive effect of these strategies on reading comprehension. In the present study, the effect of summary writing on reading comprehension has been explored. As writing demands concentration and care, summary writing effectively helps students' reading comprehension. This finding accords with that of Oczuck (2003), Heilman, Blair and Rupley (2002) and Correia (2006).

In this study, critical reading strategy was taught explicitly during a treatment period to the participants. The results confirmed Rashtchi and Aghajanzadeh (2008), Goatly (2000); Schallert and Reed (2004)findings that teaching critical reading strategies explicitly is necessary for tackling reading comprehension and more effective critical reading. 
In a recent study of Koupaee Dar and his colleagues (2010), they taught CR strategies in their reading classes and concluded that the students' motivation to learn English and read critically increased. In the present study the relationship between CR strategies and students motivation were not investigated but the researchers observed that EFL learners became more interested in critical reading after learning and using summary writing as one of CR strategies.

\section{Suggestions for Further Study}

This study has searched to find the possible effect of summary writing as a critical reading strategy on reading comprehension in intermediate EFL learners at Kish Language School in Fasa. Many other research questions may be raised in relation to the findings of this study. For example, it is not clear whether or not gender has any effect on using summary writing as a critical reading strategy. It is suggested that other researchers examine the effect of gender on using these strategies. This study can also be replicated with learners at higher or lower levels of language proficiency. Also, it can be conducted in different age groups. In addition, critical reading includes some different strategies which have not been completely studied yet, like reading with a purpose, identifying the main idea, examining subheading and illustrations and so forth. It is recommended to the researchers to investigate the impact of these strategies on reading comprehension skill. In addition, the effect of cultural factors on using critical reading strategies can be investigated.

\section{Pedagogical Implications}

The findings of the present study have some pedagogical implications for teaching and material designing. As the results of this study and other researches' (Ghahraki, 2005; Oczucks, 2003; Correia, 2006) revealed, using critical reading strategies can effectively help reading comprehension. Critical reading strategy training can be integrated into the teacher training programs. In addition, some in-service workshops should be held for the current teachers, concentrating on the importance and methods of teaching critical reading and its strategies.

Consequently, it seems useful for the students' learning that the teachers integrate critical reading strategies in their reading comprehension methodology and create the circumstances in which the students become familiar with and apply some of these strategies which are appropriate to their proficiency level and type of activity being used.

According to the results of this study, if material designers integrate the reading comprehension tasks and activities that necessitate applying critical reading strategies at the proper proficiency level of students, reading comprehension of the EFL learners will improve.

\section{Limitations of the Study}

Although an effort has been made to ensure the reliability and validity in the present study, some limitations exist. As it was really difficult for the researcher to find suitable participants (at intermediate proficiency in reading comprehension) from one city, this study was 
conducted with a small sample size including 60 participants who may not be the representative of all other EFL learners in Iran. Further studies with a large group of students may be needed to confirm the consistence of the research. This study was limited to the students at intermediate level of reading comprehension proficiency. Some studies can be conducted with participants at different levels of proficiency. In addition, only female learners participated in this study and their age ranged from 19 to 28.

\section{References}

Arju, S. (2010). Proposing opinion writing as a practice of critical thinking. The Reading Matrix, 10, 128-140.

Baleghizadeh, S., \& Babapur, M.(2011). The effect of summary writing on reading comprehension and recall of EFL Students. New England Reading Association Journal, 47(1), 44-57.

Baynham, M. (1995). Literacy practices: Investigating literacy in social contexts. London: Longman.

Bell, J. \& Gower, R. (2000). Advanced matters. London: Longman.

Belcher, D., \& Connor, U.(2001). Reflections on multi-literate lives. Clevedon: Multilingual Matters.

Bosely, L. (2008). I don't teach reading: Critical reading instruction in composition course. Literacy Research and Instruction, 47, 280- 308.

Caccamise, D. (2011). Improved reading comprehension by writing. Perspectives on Language Learning and Education, 18(1), 27-31. http://dx.doi.org/10.1044/lle18.1.27

Correia. R. (2006). Encouraging critical reading in the EFL classroom. English Teaching Forum, 9, 16-20.

Ghahraki, Sh,, \& Sharifian, F. (2005). On the relationship between overall reading comprehension and determination of fact/opinion in L2. The Reading Matrix, 5(1), 36-46.

Goatly, A. (2000). Critical reading and writing. London: Routledge.

Graham, S., \& Herbert, M.A. (2010). Writing to read: Evidence for how writing can improve reading. A Carnegie corporation time to Act Report. Washigton, DC: Alliance for Excellent Education.

Heilman, A.W., Blair, T.R., \& Rupley, W.H. (2002). Principles and practices of teaching reading. Upper River, N.J.: Merrill Prentice Hall.

Icmez, S. (2009). Motivation and critical reading in EFL classroom: A case of ELT preparatory students. Journal of Theory and Practice in Education, 5(2), 123-147. from http://eku.Comu.edu.tr/index.

Koupaee Dar, Z., Rahimi, A., \& Shams, M.R. (2010). Teaching reading with a critical attitude: Using critical discourse analysis (CDA) to raise EFL university students' critical language 
awareness. International Journal of Criminology and Sociology Theory, 3(2), 457- 476.

Missori, L. (2007). Applying critical thinking to reading, Longview Community College. Retrieved June 20, 2010, Retrieved from http//www. ss. Critical thinking.html.

Nassrollahi, M.A. (2007). The effect of critical reading strategy on improvement of reading comprehension autonomy of EFL learners. Paper presented at the fifth Asian TEFL International Conference, Kulala Lumpur, Malaysia.

Oczucks, L. (2003). Reciprocal teaching at work: Strategies for improving reading comprehension. Newark, DE: International Reading Association.

Pakzadian, M. \& Eslami Rasekh, A. (2012). The effect of using summarization strategies on Iranian EFL learners' reading comprehension. English Linguistics Research, 1(1), 118-125. http://dx.doi.org/10.5430/elr.v1n1p118

Rashtchi, M., \& Aghajanzadeh, M. (2008). Comparative critical reading strategy and writing achievement of Iranian EFL learners. The Journal of Applied Linguistics, 1(2), 117- 130 .

Saslow, J., \& Ascherscher, A. (2006). Summit: English for today's world 1B. NY: Pearson Education Inc.

Schallert, D., \& Reed, J. (2004). Intellectual, motivational, textual and cultural considerations in teaching and learning with computer- mediated discussion. Journal of Research Technology in Education, 36(2), 103-119.

Sharpe, P.J. (2007). Practice exercises for the TOEFL test, $4^{\text {th }}$ edition.

Shen, M.Y. (2009). Reading writing connection for EFL college learners' literacy development. Asian EFL Journal, 11(1), 68-79.

Spack, R. (1997). The acquisition of academic literacy in a second language: A longitudinal case Study. Written $\quad$ Communication, $14(1), 62$. http://dx.doi.org/10.1177/0741088397014001001

Wallace, C. (1992). Critical literacy awareness in the EFL classroom. In Critical language awareness, N. Fairclough, (Ed.), 59-92. London: Longman.

Wallace, C. (2003). Critica reading in language education. New York: Palgrave Macmilla. http://dx.doi.org/10.1057/9780230514447 